\title{
PENGARUH DESENTRALISASI, STRATEGI BISNIS DAN PEMANFAATAN INFORMASI SISTEM AKUNTANSI MANAJEMEN TERHADAP KINERJA MANAJERIAL PADA PT BANK MANDIRI DI MANADO
}

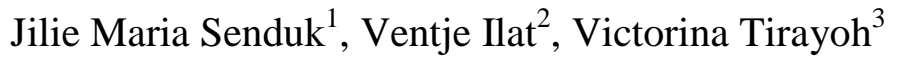 \\ 1,2,3 Jurusan Akuntansi, Fakultas Ekonomi dan Bisnis, Universitas Sam Ratulangi, Jl. Kampus Bahu, Manado, \\ 95115, Indonesia \\ E-mail : jiliemaria96@gmail.com
}

\begin{abstract}
To be able to leading in today's global competition, companies must have an effective, fast and precise decision-making level. PT Bank Mandiri is the largest BUMN banking services company in Indonesia that has expanded overseas. This research aimed to examine the influence of decentralization, business strategy and the utilization of information management accounting system on managerial performance at PT Bank Mandiri in Manado. Population in this research are the managers and officers on manager level at Bank Mandiri Area Manado and Mandiri KCP Manado. This research used purposive sampling technique. This research used questionnaires to collect data from 34 respondents. This research used primary data obtained questionnaires. Data analysis was performed with multiple linear regression analysis. The result of this research showed that decentralization has a significant positive effect on managerial performance, business strategy has not effect on managerial performance and information management accounting system has a significant positive effect on managerial performance at PT Bank Mandiri in Manado.
\end{abstract}

Keywords: Decentralization, Business Strategy, Information Management Accounting System, Managerial Performance

\section{PENDAHULUAN}

Kemajuan zaman dan pertumbuhan ekonomi yang intens saat ini mengakibatkan adanya peningkatan persaingan dalam dunia perekonomian. Industri perbankan pun selalu mengalami tantangan dari persaingan global. Indonesia merupakan negara dengan jumlah bank yang paling banyak di ASEAN. Dunia perbankan dituntut untuk beradaptasi dengan lingkungan yang sangat kompetitif serta merespon ancaman yang ada saat ini. Untuk dapat unggul dalam persaingan global saat ini, perusahaan harus memiliki tingkat pengambilan keputusan yang efektif, cepat dan tepat salah satunya dengan adanya desentralisasi yang juga dapat meningkatkan strategi bisnis, serta dengan adanya pemanfaatan informasi sistem akuntansi manajemen dapat membantu perusahaan menciptakan kinerja perusahaan yang berkualitas dan kompetitif.

Desentralisasi merupakan pendelegasian wewenang dan tanggung jawab kepada para manajer. Strategi lebih berkaitan dengan memutuskan apa yang tidak dilakukan, juga berkaitan dengan memutuskan apa yang dilakukan, manajer harus mempertimbangkan pilihan strategi bisnis dalam mencapai keunggulan kompetitif (Aji Prasetio. 2015: 2). Proses pengambilan keputusan dalam suatu perusahaan memerlukan dukungan informasi, terutama bagi para manajer yang berperan penting dalam pengambilan keputusan. Chenhall \& Morris (1986) mengemukakan bahwa terdapat empat karakteristik informasi sistem akuntansi manajemen yang berpengaruh dalam pengambilan keputusan yaitu; broadscope (lingkup luas), timeliness (tepat waktu), aggregation (agregat), dan intergration (integrasi). Dari keempat karakteristik sistem informasi akuntansi manajemen tersebut penelitian ini berfokus pada karakteristik broadscope karena karakteristik ini memiliki cakupan luas. 
Dalam usaha untuk menciptakan kinerja perusahaan yang unggul, tentu saja dibutuhkan suatu kinerja manajerial yang berkualitas tinggi. Kinerja digunakan untuk mengukur tingkat keberhasilan atau kegagalan dalam mencapai tujuan sebuah perusahaan secara efesien dan efektif.

Penelitian ini menggunakan perusahaan jasa perbankan BUMN yang ada di Manado sebagai objek yang akan diteliti yaitu pada PT Bank Mandiri. Alasan dilakukan pada perusahaan perbankan khususnya pada PT Bank Mandiri adalah karena PT Bank Mandiri merupakan perusahaan jasa perbankan BUMN terbesar di Indonesia yang telah memiliki ekspansi ke luar negeri yang menuntutnya untuk lebih unggul dalam persaingan global.

\section{Tujuan Penelitian}

Tujuan penelitian yang ingin dicapai dalam penelitian ini adalah sebagai berikut :

1. Untuk mengetahui pengaruh desentralisasi terhadap kinerja manajerial pada PT Bank Mandiri di Manado.

2. Untuk mengetahui pengaruh strategi bisnis terhadap kinerja manajerial pada PT Bank Mandiri di Manado.

3. Untuk mengetahui pengaruh informasi sistem akuntansi manajemen terhadap kinerja manajerial pada PT Bank Mandiri di Manado.

\section{TINJAUAN PUSTAKA}

\section{Konsep Akuntansi}

Menurut American Institute of Certified Public Accountants (AICPA) (1953), dalam Accounting Terminology Bulletin No.1: Akuntansi adalah suatu seni pencatatan, pengklasifikasian dan pengikhtisaran dengan suatu cara tertentu, yang dinyatakan dalam uang, transaksi dan peristiwa, paling tidak mengenai karakter keuangan dan penafsiran hasil. (Ishak The \& Sugiono, 2015: 2).

\section{Akuntansi Manajemen}

Salman \& Farid (2016: 2-4) Akuntansi manajemen adalah pengembangan dan penerapan berbagai teknik pencatatan (recording), analisis, interpretasi dan presentasi, membuat perhitungan keuangan, perhitungan biaya, dan data lain yang aktif dan efektif dalam menjalankan fungsi kinerja manajerial, yaitu, perencanaan, pengambilan keputusan dan pengendalian. Akuntansi manajemen diharapkan dapat membantu manajemen dalam proses pengambilan keputusan agar keputusan-keputusan ekonomi yang dikuasainya atau kekayaan perusahaan dapat dialokasikan dan ditransformasikan secara lebih efektif serta efisien.

\section{Desentralisasi}

Desentralisasi adalah pendelegasian wewenang kepada manajer yang arasnya lebih rendah. Wenang yang didelegasikan kepada manajer bawahan itu beraneka ragam. Pada titik terendah hanya keputusan beban yang didelegasikan. Pusat beban merupakan pusat pertanggungjawaban yang menerima delegasi wewenang terendah ini. Pada titik tertinggi, wewenang yang didelegasikan sangat luas yang meliputi keputusan bebas, pendapatan, laba dan investasi (Sodikin, 2015: 234).

\section{Strategi Bisnis}

Strategi bisnis (business strategy) merupakan strategi yang dibuat pada level unit bisnis dan strateginya lebih ditekankan untuk meningkatkan posisi bersaing produk atau jasa perusahaan di dalam suatu industri atau segmen pasar tertentu (Solihin, 2012: 196). 
Hasil penelitian Miles dan Snow (1978) mengidentifikasikan empat tipe strategi bisnis yang sering digunakan oleh perusahaan, yaitu:

a. Prospector. Perusahaan yang tergolong dalam tipe strategi prospector adalah perusahaan yang secara terus menerus mencari peluang-peluang pasar baru dengan berkompetisi melalui produk baru dan market development serta bereksperimen dengan melakukan respon-respon potential terhadap kecenderungan lingkungan yang timbul.

b. Defender. Strategi defender yaitu apabila perusahaan tersebut beroperasi pada area produksi yang relative stabil, produk yang ditawarkan bersifat terbatas dibandingkan kompetitornya dan perusahaan jarang melakukan penyesuaian-penyesuaian dalam teknologi dan struktur atau metode operasi perusahaan.

c. Analyzer. Strategi analyzer merupakan kombinasi dari prospector dan defender. Perusahaan beroperasi dalam dua tipe domain produk pasar yang relatif stabil dan tetap melakukan perubahan-perubahan. Jika berada dalam area stabil, maka perusahaan akan beroperasi secara rutin dan efisien dengan menggunakan struktur-struktur dan prosesproses yang telah diformulasikan sebelumnya.

d. Reactor. Strategi reactor merupakan strategi perusahaan yang manajer puncaknya seringkali menerima perubahan dan ketidakpastian yang terjadi dalam lingkungan organisasinya, tetapi tidak meresponnya secara efektif.

\section{Informasi Sistem Akuntansi Manajemen}

Informasi akuntansi manajemen merupakan informasi keuangan dan non keuangan, semakin sering disajikan, maka semakin banyak informasi yang diperoleh untuk membantu semua pihak yang berkepentingan dalam perencanaan, pengendalian dan pengambilan keputusan yang akan meningkatkan kinerja manajerial (Rahayu, 2013).

Sistem informasi akuntansi manajemen (management accounting information system) adalah sistem informasi akuntansi yang mentransformasi input dengan menggunakan proses untuk menghasilkan output yang dibutuhkan untuk mendukung pengambilan keputusan (Siregar, dkk. 2013: 5).

Chenhall dan Morris (1986) mengidentifikasi empat karakteristik informasi sistem akuntansi manajemen yaitu sebagai berikut :

a. Broadscope. Lingkup sistem akuntansi manajemen yang luas memberikan informasi yang berhubungan dengan lingkungan eksternal yang mungkin bersifat ekonomi seperti Gross National Product, total penjualan pasar dan pangsa pasar suatu industry, atau juga bersifat non ekonomi seperti factor demografi, cita rasa konsumen, tindakan para pesaing dan perkembangan teknologi. Disamping itu, lingkup sistem akuntansi manajemen yang luas akan memberikan estimasi tentang kemungkinan terjadinya peristiwa di masa yang akan dating dalam ukuran probabilitas.

b. Timeliness. Informasi timeliness meningkatkan fasilitas sistem akuntansi manajemen untuk melaporkan peristiwa paling akhir dan untuk memberikan umpan balik secara tepat terhadap keputusan yang dibuat. Jadi timeliness mencakup frekuensi pelaporan dan kecepatan pelaporan.

c. Aggregation. Tipe aggregasi yang mangacu pada berbagai format yang konsisten dengan model keputusan formal seperti analisis cash flow yang didiskontokan untuk anggaran modal, simulasi dan linier programming untuk penerapan anggaran, analisis laba dan rugi dan analisis pengendalian intern.

d. Integration. Aspek pengendalian suatu organisasi yang penting adalah koordinasi berbagai segmen dalam sub-sub organisasi. Karakteristik sistem akuntansi manajemen yang membantu koordinasi mencakup spesifikasi target yang menunjukkan pengaruh interaksi segmen dan informasi mengenai pengaruh keputusan pada operasi seluruh subunit organisasi. 


\section{Kinerja Manajerial}

Kinerja manajerial merupakan salah satu faktor yang dapat meningkatkan keefektifan organisasi, situasi dan lingkungan yang berubah-ubah (dinamis) menuntut pihak manajemen untuk selalu mengikuti perubahan, apabila tidak maka keputusan yang diambil serta tindakan organisasi tidak akan sesuai dengan tujuan organisasi. Tujuan pokok penilaian kinerja adalah untuk memotivasi karyawan dalam mencapai sasaran organisasi dan dalam mematuhi standar perilaku yang telah ditetapkan sebelumnya, agar membuahkan tindakan dan hasil yang diinginkan (Frestilia, 2013).

\section{Hipotesis}

H1 = Desentralisasi berpengaruh signifikan positif terhadap Kinerja Manajerial

$\mathrm{H} 2=$ Strategi Bisnis berpengaruh signfikan positif terhadap Kinerja Manajerial

H3 = Informasi Sistem Akuntansi Manajemen berpengaruh signifikan positif terhadap kinerja manajerial

\section{Penelitian Terdahulu}

1. Penelitian yang dilakukan oleh Afrida (2013), menunjukkan bahwa desentralisasi memiliki pengaruh yang signifikan positif terhadap kinerja manajerial dan semakin tinggi penerapan desentralisasi akan meningkatkan kinerja manajerial.

2. Penelitian yang dilakukan oleh Fitriani (2013), menunjukkan bahwa penggunaan karakteristik informasi akuntansi manajemen bersifat broadscope akan meningkatkan kinerja manajerial.

3. Penelitian yang dilakukan oleh Paylosa (2014), menunjukkan bahwa informasi sistem akuntansi manajemen bersifat broadscope akan meningkatkan kinerja manajerial.

\section{METODE PENELITIAN}

Jenis Penelitian

Penelitian ini merupakan penelitian asosiatif. Penelitian asosiatif merupakan penelitian yang bertujuan untuk mengetahui hubungan antara dua variabel atau lebih serta mengetahui pengaruhnya (Sujarweni, 2014: 11). Dalam penelitian ini bertujuan untuk mengetahui Pengaruh Desentralisasi, Strategi Bisnis dan Pemanfaatan Informasi Sistem Akuntansi Manajemen Terhadap Kinerja Manajerial.

\section{Tempat dan Waktu Penelitian}

Penelitian ini dilakukan pada PT Bank Mandiri di Manado, yaitu pada Mandiri Kantor Cabang Manado Dotulolong Lasut (Jl. Dotulolong Lasut No. 15), Mandiri KCP Manado Toar (J1. Toar No. 4-6), Mandiri KCP Manado Sudirman (Jl. Jendral Sudirman No. 47), Mandiri KCP Manado Sam Ratulangi (Kompleks Wanea Plaza Blik I No. 8, Jl. Sam Ratulangi), Mandiri KCP Manado Bahu (Komplek Bahu Mall S/12, Jl. Wolter Monginsidi, Bahu). Penelitian ini dilakukan pada bulan Mei 2017.

\section{Populasi dan Sampel}

Populasi dalam penelitian ini adalah pihak manajerial PT Bank Mandiri pada Kantor Cabang dan Kantor Cabang Pembantu di Manado yang berjumlah 39 orang.

Teknik pengambilan sampel dalam penelitian ini berupa purposive sampling. Sampel dalam penelitian ini adalah sebanyak 34 orang. Adapun kriteria dalam penelitian ini difokuskan pada tiap-tiap manajer atau level manajer, didasarkan karena para manajer atau level manajer berperan penting dalam pengambilan keputusan dalam bank tersebut. 


\section{Jenis dan Sumber Data}

Penelitian ini menggunakan metode analisis data kuantitatif yaitu menggunakan rumus-rumus statisktik yang disesuaikan judul penelitian dan rumusan masalah, untuk perhitungan angka-angka dalam rangka menganalisis data yang diperoleh dari pihak manajerial pada Bank Mandiri di Manado. Sumber data yang digunakan dalam penelitan ini yaitu data primer yang diperoleh secara langsung melalui pembagian kuesioner pada pihak manajerial pada Bank Mandiri di Manado.

\section{Teknik Pengumpulan Data}

Teknik pengumpulan data yang dilakukan adalah dengan menggunakan metode kuesioner tipe tertutup yakni berisi pernyataan yang mengharapkan responden untuk memilih salah satu alternative jawaban dari setiap pernyataan yang telah tersedia (Sugiyono, 2013: 142-143). Dalam hal ini peneliti melakukan pembagian kuesioner untuk pihak manajerial pada Bank Mandiri di Manado.

\section{Definisi dan Pengukuran Variabel Operasional}

$\mathrm{Y} \quad=$ Kinerja Manajerial, variabel ini diukur dengan skala likert.

$\mathrm{X}_{1} \quad=$ Desentralisasi, variabel ini diukur dengan skala likert.

$\mathrm{X}_{2} \quad=$ Strategi Bisnis, variabel ini diukur dengan skala likert.

$\mathrm{X}_{3}=$ Informasi Sistem Akuntansi Manajemen, variabel ini diukur dengan skala likert.

\section{Metode Analisis}

Metode yang digunakan untuk menganalisis data instrumen penelitian berupa kuesioner adalah uji kualitas data dengan melakukan uji validitas dan uji reabilitas. Selanjutnya agar hasil perhitungan dapat diinterprestasikan dengan akurat dilakukan uji asumsi klasik yang meliputi uji normalitas, uji multikolonieritas dan uji heteroskedastisitas. Terakhir, dilakukan pengujian terhadap model regresi linear berganda yang meliputi uji koefisien determinasi $\left(\mathrm{R}^{2}\right.$ ), uji signifikan simultan (uji $\mathrm{F}$ ), dan uji signifikan parameter individual (uji t). Semua uji analisis ini dilakukan dengan bantuan software SPSS Statistic versi 24.

\section{HASIL PENELITIAN DAN PEMBAHASAN Sejarah Singkat Bank Mandiri}

Bank Mandiri didirikan pada 2 Oktober 1998, sebagai bagian dari program restrukturisasi perbankan yang dilaksanakan oleh pemerintah Indonesia. Pada bulan Juli 1999, empat bank pemerintah -- yaitu Bank Bumi Daya, Bank Dagang Negara, Bank Ekspor Impor Indonesia dan Bank Pembangunan Indonesia -- dilebur menjadi Bank Mandiri, dimana masing-masing bank tersebut memiliki peran yang tak terpisahkan dalam pembangunan perekonomian Indonesia. Sampai dengan hari ini, Bank Mandiri meneruskan tradisi selama lebih dari 140 tahun memberikan kontribusi dalam dunia perbankan dan perekonomian Indonesia.

\section{Hasil Penelitian}

Dalam penelitian ini responden yang digunakan adalah para manajer dan tingkatan manajer yang ada pada Mandiri Kantor Cabang Manado Dotulolong Lasut, Mandiri Kantor Cabang Pembantu Manado Toar, Mandiri Kantor Cabang Pembantu Manado Sudirman, Mandiri Kantor Cabang Pembantu Manado Bahu dan Mandiri Kantor Cabang Pembantu Manado Sam Ratulangi. Adapun jumlah manajer yang ada dalam Bank Mandiri Kantor Cabang dan Kantor Cabang Pembantu di Manado adalah sebanyak 39 manajer dan semua manajer dijadikan sebagai sampel dalam penelitian ini. 
Penyebaran kuesioner dilakukan pada tanggal 22 Mei 2017 sampai dengan tanggal 29 Mei 2017. Dari jumlah 39 kuesioner yang dibagikan, jumlah kuesioner yang dikembalikan adalah sebanyak 34 kuesioner.

\section{Uji Kualitas Data}

Untuk melihat apakah data yang diperoleh dari kuesioner yang dibagikan dapat dipercaya dilakukan uji validitas dan uji reliabilitas. Penelitian ini telah lulus uji validitas dan uji reliabilitas.

\section{Uji Asumsi Klasik}

Agar hasil penelitian dapat diinterprestasikan dengan akurat maka dilakukan uji asumsi klasik. Penelitian ini telah lulus uji normalitas, multikolinieritas serta heterokedastisitas.

\section{Uji Hipotesis}

Uji Koefisien Determinasi $\left(\mathbf{R}^{2}\right)$

Model Summary

\begin{tabular}{crrrr}
\hline Model & R & R Square & Adjusted R Square & \multicolumn{2}{c}{$\begin{array}{c}\text { Std. Error of the } \\
\text { Estimate }\end{array}$} \\
\hline 1 & $.730^{\mathrm{a}}$ & .532 & .485 & 1.489 \\
\hline
\end{tabular}

a. Predictors: (Constant), X3, X2, X1

Sumber: Data Primer yang Diolah (2017)

Hasil menunjukkan nilai Adjusted R Square sebesar 0,485 atau sebesar 48,5\%. Hal itu menunjukkan bahwa ketiga variabel Independen yaitu Desentralisasi, Strategi Bisnis dan Informasi Sistem Akuntansi Manajemen berpengaruh sebesar 48,5\% terhadap Kinerja Manajerial. Sementara itu sebesar 51,5\% (100\% - 48,5\%) lainnya dijelaskan oleh variabel lain diluar variabel independen yang digunakan.

\section{Uji Signifikan Simultan (Uji F)}

\begin{tabular}{|c|c|c|c|c|c|c|}
\hline \multicolumn{2}{|c|}{ Model } & Sum of Squares & $\mathrm{df}$ & Mean Square & $\mathrm{F}$ & Sig. \\
\hline 1 & Regression & 75.711 & 3 & 25.237 & 11.376 & $.000^{\mathrm{b}}$ \\
\hline & Residual & 66.553 & 30 & 2.218 & & \\
\hline & Total & 142.265 & 33 & & & \\
\hline
\end{tabular}

a. Dependent Variable: Y

b. Predictors: (Constant), X3, X2, X1

Sumber: Data Primer yang Diolah (2017)

Hasil perbandingan antara $\mathrm{F}$ hitung dan $\mathrm{F}$ tabel yaitu $\mathrm{F}$ hitung $=11.376>\mathrm{F}$ tabel $=2,91$ dengan tingkat signifikan $0,00<0,05$. Maka dapat disimpulkan bahwa seluruh variabel independen yaitu Desentralisasi, Strategi Bisnis dan Informasi Sistem Akuntansi Manajemen secara bersama sama mempengaruhi variabel dependen Kinerja Manajerial secara positif dan signifikan. 


\section{Uji Signifikan Parameter Individual (Uji t)}

\begin{tabular}{|c|c|c|c|c|c|}
\hline \multirow[b]{2}{*}{ Model } & \multicolumn{2}{|c|}{$\begin{array}{c}\text { Unstandardized } \\
\text { Coefficients }\end{array}$} & \multirow{2}{*}{$\begin{array}{c}\text { Standardized } \\
\text { Coefficients } \\
\text { Beta } \\
\end{array}$} & \multirow[t]{2}{*}{$\mathrm{t}$} & \multirow[b]{2}{*}{ Sig. } \\
\hline & B & Std. Error & & & \\
\hline (Constant) & 13.551 & 5.103 & & 2.655 & .013 \\
\hline Desentralisasi & .248 & .087 & .382 & 2.846 & .008 \\
\hline Strategi Bisnis & -.242 & .145 & -.223 & -1.670 & .105 \\
\hline $\begin{array}{l}\text { Informasi } \\
\text { Sistem } \\
\text { Akuntansi } \\
\text { Manajemen }\end{array}$ & .657 & .245 & .378 & 2.688 & .012 \\
\hline
\end{tabular}

a. Dependent Variable: Y

Sumber: Data Primer yang Diolah (2017)

\section{H1 : Desentralisasi berpengaruh signifikan positif terhadap Kinerja Manajerial}

Variabel Desentralisasi menunjukkan nlai t hitung sebesar 2.846 yang berarti $>\mathrm{t}$ tabel $(2,042)$ dan nilai signifikan $0,008<0,05$. Hal ini menunjukkan bahwa secara individu atau parsial Desentralisasi berpengaruh signifikan positif terhadap Kinerja Manajerial. Maka hipotesis $\mathbf{H 1}$ diterima.

\section{H2 : Strategi Bisnis berpengaruh signifikan positif terhadap Kinerja Manajerial}

Variabel Strategi Bisnis menunjukkan nilai t hitung sebesar -1.670 yang berarti $<\mathrm{t}$ tabel $(2,042)$ dan nilai signifikan 0,105 > 0,05. Hal ini menunjukkan bahwa secara individu atau parsial Strategi Bisnis tidak berpengaruh terhadap Kinerja Manajerial. Maka hipotesis H2 ditolak.

\section{H3 : Informasi Sistem Akuntansi Manajemen berpengaruh signifikan positif terhadap Kinerja Manajerial}

Variabel Karakteristik Informasi Sistem Akuntansi Manajemen menunjukkan nilai t hitung sebesar 2,688 yang berarti $>t$ tabel $(2,042)$ dan nilai signifikan $0,012<0,05$. Hal ini menunjukkan bahwa secara individu atau parsial Informasi Sistem Akuntansi Manajemen berpengaruh signifikan positif terhadap Kinerja Manajerial. Maka hipotesi H3 diterima.

Berdasarkan tabel persamaan regresi linear berganda dapat ditulis sebagai berikut:

$$
\begin{aligned}
& Y=\alpha+\beta_{1} X_{1}+\beta_{2} X_{2}+\beta_{3} X_{3}+e \\
& Y=13,551+\mathbf{0 , 2 4 8} X_{1}-\mathbf{0 , 2 4 2} X_{2}+\mathbf{0 , 6 7 5} X_{3}
\end{aligned}
$$

\begin{tabular}{|c|c|}
\hline Y & $\begin{array}{l}=\text { Kinerja Manajerial } \\
=\text { Konstanta }\end{array}$ \\
\hline $\mathrm{X} 1$ & $=$ Desentralisasi \\
\hline $\mathrm{X} 2$ & $=$ Strategi Bisnis \\
\hline $\mathrm{X} 3$ & $=$ Informasi Sistem Akuntansi Manajeme \\
\hline$\beta 1 \beta 2 \beta 3$ & $\begin{array}{l}=\text { Koefisien regresi } \\
=\text { Standar error }\end{array}$ \\
\hline
\end{tabular}

Dimana: 


\section{PEMBAHASAN}

\section{Pengaruh Desentralisasi terhadap Kinerja Manajerial}

Dalam penelitian ini menunjukkan bahwa desentralisasi berpengaruh signifikan positif terhadap kinerja manajerial. Hasil penelitian ini mendukung hasil penelitian dari Afrida (2013) yang menyatakan bahwa desentralisasi berpengaruh secara signifikan positif terhadap kinerja manajerial. Pendelegasian wewenang sangat penting diberikan kepada pihak manajerial dan para manajer bawahannya agar para manajer dapat mengetahui serta merespon dengan cepat dan tepat tentang kondisi-kondisi ekonomi dan kultur dalam lingkungan sekitar. Dengan demikian desentralisasi dapat meningkatkan efektivitas kinerja manajerial.

\section{Pengaruh Strategi Bisnis terhadap Kinerja Manajerial}

Dalam penelitian ini menunjukkan bahwa strategi bisnis tidak berpengaruh terhadap kinerja manajerial. Hasil penelitian ini sejalan dengan hasil penelitian dari Putri (2014) yang menyatakan strategi bisnis prospectors tidak berpengaruh terhadap kinerja manajerial melalui karakteristik sistem akuntansi manajemen broadscope. Hasil pengujian yang tidak berhasil menemukan adanya pengaruh yang signifikan diduga karena adanya kemungkinan strategi yang dipakai masih belum beriringan dengan besarnya kompetensi yang dimiliki oleh para manajer untuk meresponi kekuatan dan kelemahan sumber daya yang ada dalam dunia perbankan. Kemudian usaha dan kerja sama untuk meningkatkan profitabilitas dapat diperhatikan dan dikembangkan. Oleh karena itu kerja sama manajer dalam rangka meningkatkan kompetensi dan profitabilitas strategi bisnis dapat meningkatkan kinerja manajerial yang lebih baik.

\section{Pengaruh Informasi Sistem Akuntansi Manajemen terhadap Kinerja Manajerial}

Dalam penelitian ini informasi sistem akuntansi manajemen bersifat broadscope berpengaruh signifikan positif terhadap kinerja manajerial. Hasil penelitian ini mendukung hasil penelitian dari Fitriani (2013) yang menyatakan bahwa penggunaan informasi sistem akuntansi manajemen yang bersifat broadscope berpengaruh signifikan positif. Informasi sangat dibutuhkan oleh pihak manajerial perusahaan terutama perusahaan perbankan agar dapat membuat keputusan yang sejalan dengan kondisi-kondisi yang ada di lingkungan sekitarnya. Informasi yang luas akan mendukung para manajer untuk dapat beradaptasi dengan kondisi yang memiliki ancaman dan juga kondisi-kondisi yang menguntungkan perusahaan. Maka semakin tinggi informasi sistem akuntansi manajemen ini diperoleh pihak manajer akan meningkatkan kinerja manajerial.

\section{PENUTUP}

\section{Kesimpulan}

Berdasarkan hasil analisis dan pembahasan mengenai Pengaruh Desentralisasi, Strategi Bisnis dan Pemanfaatan Informasi Sistem Akuntansi Manajemen Terhadap Kinerja Manajerial Pada PT Bank Mandiri di Manado maka dapat ditarik kesimpulan sebagai berikut:

1. Hasil penelitian ini menunjukkan bahwa Desentralisasi berpengaruh signifikan positif terhadap Kinerja Manajerial pada PT Bank Mandiri di Manado.

2. Hasil penelitian ini menunjukkan bahwa Strategi Bisnis tidak berpengaruh terhadap Kinerja Manajerial pada PT Bank Mandiri di Manado.

3. Hasil penelitian ini menunjukkan bahwa Informasi Sistem Akuntansi Manajemen berpengaruh signifikan positif terhadap Kinerja Manajerial pada PT Bank Mandiri di Manado. 


\section{Saran}

Dengan memperhatikan hasil analisis dan kesimpulan maka saran yang dapat diberikan adalah sebagai berikut:

1. Bagi peneliti selanjutnya agar dapat memperbanyak dan memperluas sampel yang akan diteliti agar hasil yang akan didapatkan lebih akurat dari penelitian sebelumnya. Selain itu dapat menambahkan butir pernyataan dalam kuesioner. Dapat menggunakan karakteristik-karakteristik dari informasi sistem akuntansi manajemen yang lainnya seperti timeliness aggregation atau integration.

2. Bagi perusahaan untuk lebih meningkatkan desentralisasi agar keefektifan kinerja manajerial lebih meningkat, tentunya dengan dukungan informasi sistem akuntansi manajemen yang selalu menjadi arahan pada pengambilan keputusan. Serta meningkatkan perumusan strategi yang lebih melibatkan keikutsertaan para manajer atau karyawan dari perusahaan.

\section{DAFTAR PUSTAKA}

Afrida, Nur. 2013. Pengaruh Desentralisasi dan Sistem Pengendalian Intern Pemerintah Terhadap Kinerja Manajerial SKPD. Jurnal Akuntansi. Vol. 1, No. 2.

Aji, Prasetio. 2015. Manajemen Strategi Keunggulan Bersaing Berkelanjutan. Yogyakarta: Ekuilibria.

Chenhall, R H. dan Morris. 1986. The Impact of Structure, Environment and Interpendence on the Perceived Usefullness of Management Accounting System. The Accounting Review. Vol. 61, No.1.

Fitriani. 2013. Pengaruh Penggunaan Karakteristik Informasi Akuntansi Manajemen Terhadap Kinerja Manajerial. Jurnal Akuntansi. Vol. 1, No. 3.

Frestilia, Nindhy, 2013. Pengaruh pemanfaatan Teknologi Informasi, Karakteristik Informasi Sistem Akuntansi Manajemen dan Ketidakpastian Lingkungan Terhadap Kinerja Manajerial Studi Empiris Pada Perusahaan Perbankan di Kota Padang. Jurnal Akuntansi. Vol. 1, No.1.

Ishak The., dan Sugiono. 2015. Akuntansi, Informasi Dalam Pengambilan Keputusan. Jakarta: PT. Grasindo

Ismail Solihin. 2012. Manajemen Strategik. Jakarta: Erlangga.

Miles, R E., dan Snow, C. 1978. Organizational Strategy, Structural, and Process. New York, NY: McGraw-Hill.

Paylosa, Fanny, 2014. Pengaruh Strategi Bisnis dan Desentralisasi Terhadap Hubungan Antara Pemanfaatan Informasi Sistem Akuntansi Manajemen dan Kinerja Manajerial studi Empiris Pada Perusahaan Jasa Perhotelan di Kota Padang dan Bukittinggi. Jurnal Akuntansi. Vol. 2, No.1.

Putri, Lisa Khairina. 2014. Pengaruh Ketidakpastian Lingkungan dan Strategi Bisnis Terhadap Kinerja Manajerial Dengan Karakteristik Sistem Akuntansi Manajemen Sebagai Variabel Intervening (Studi Empiris pada Perusahaan Jasa Perhotelan di Kota Padang dan Kota Bukittingi). Jurnal Akuntansi. Vol. 2, No. 2.

Rahayu, Melani. 2013. Pengaruh Intensitas Informasi Akuntansi Manajemen Terhadap Kinerja Manajerial Dengan Ketidakpastian Lingkungan Sebagai Variabel Intervening (Studi Empiris Perusahaan Manufaktur di Kota Padang). Jurnal Akuntansi. Vol. 1, No. 1.

Salman, Kautsar., Farid, Mochammad. 2016. Akuntansi Manajemen Alat Pengukuran dan Pengambilan Keputusan Manajerial. Jakarta: Indeks.

Siregar, B., Suripto, B., Hapsoro, D., Widodo Lo, E., Biyanto, F. 2013. Akuntansi Manajemen. Jakarta: Salemba Empat. 
Sodikin, Slamet. 2015. Akuntansi Manajemen Sebuah Pengantar, Edisi Kelima. Yogyakarta: Unit Penerbit dan Percetakan Sekolah Tinggi Ilmu Manajemen YKPN.

Sugiyono. 2013. Metode Penelitian Pendidikan (Pendekatan Kuantitatif, Kualitatif, dan $R \& D)$. Bandung: Alfabeta.

Sujarweni, V. W. 2014. Metode Penelitian. Yogyakarta: PUSTAKA BARU PRESS. 